\title{
The Gentrification of Consumption: a View from Manchester
}

\author{
by Joanne Massey \\ Manchester Metropolitan University
}

\author{
Sociological Research Online, Volume 10, Issue 2, \\ < http://unw. socresonline.org.uk/10/2/massey1.htm/> \\ doi:10.5153/sro. 1099
}

Received: 13 Oct 2004 Accepted: 20 May 2005 Published: 30 Jun 2005

\begin{abstract}
This article gives some insight into the processes underpinning the exclusion of small traders from of the redevelopment of Manchester after the IRA bombing in 1996. This is achieved by drawing upon interviews with former traders of the Corn Exchange. This is a small subsection of a broader set of qualitative data which was gathered (between 2001 and 2002) from past and present everyday users of the Millennium Quarter. I claim that through regeneration the Millennium Quarter has experienced intense gentrification in which it has been reconfigured as an exclusive site of consumption (Smith 1996, Zukin 1995) which caters for the needs of the affluent. This gentrification is not only influenced by the middle classes who it is designed to attract but by private developers (Hackworth 2002) and often state intervention (Hackworth and Smith 2001). I draw on literature reflecting the experience of American cities (Betancur 2002, Hackworth 2002, Hackworth and Smith 2001, Zukin 1995) and more recent work about the rebuilding of Manchester (Holden 2002, Mellor 2002, Williams 2000). Whilst a significant body of literature exists regarding British cities (Atkinson 2000, Butler and Robson 2001, Hamnett and Randolph 1984, Robson and Butler 2001, Rosenburg and Watkins 1999) much of this concentrates on housing and residential areas. This paper is about the Millennium Quarter which is primarily a retail site in the central urban core and it adds to a growing literature regarding city centre redevelopment (e.g.; Chatterton and Hollands (2003); Low (2000) Van der Land (this collection).
\end{abstract}

\section{Keywords: Xx}

\section{Introduction}

1.1 The empirical aspects of this paper are based upon a small population (seven traders) displaced by the IRA bombing in Manchester. The aim is to contextualise their stories of marginalisation and exclusion in terms of broader social change in Manchester. This group from the Corn Exchange shared the common experience of trading within a particular space in the city centre. They expressed views that the Corn Exchange was a valuable space for selling and consuming goods. This value has, in their opinion, been lost post-bomb. Without a doubt they were substantial 'losers' in economic and social terms, as their building was seriously damaged and they were forced to cease trading.

"There were a significant number of angry and discontented voices - notably those concerned with the treatment of employees and retailers in the Corn Exchange and Royal Exchange" (Holden 2002: 138)

1.2 The central objective of this article is to bring into the public arena the views of those excluded from the rebuilding process, via the power mechanisms discussed over the following pages. Though the sample analysed here is relatively small their views are nonetheless germane (could you back this up by saying that they are one sub-set of your data and although it is beyond the scope of this paper other groups had similar stories of exclusion). Before commencing this story though it is salient to give an overview of the debate surrounding gentrification and its meaning. . 


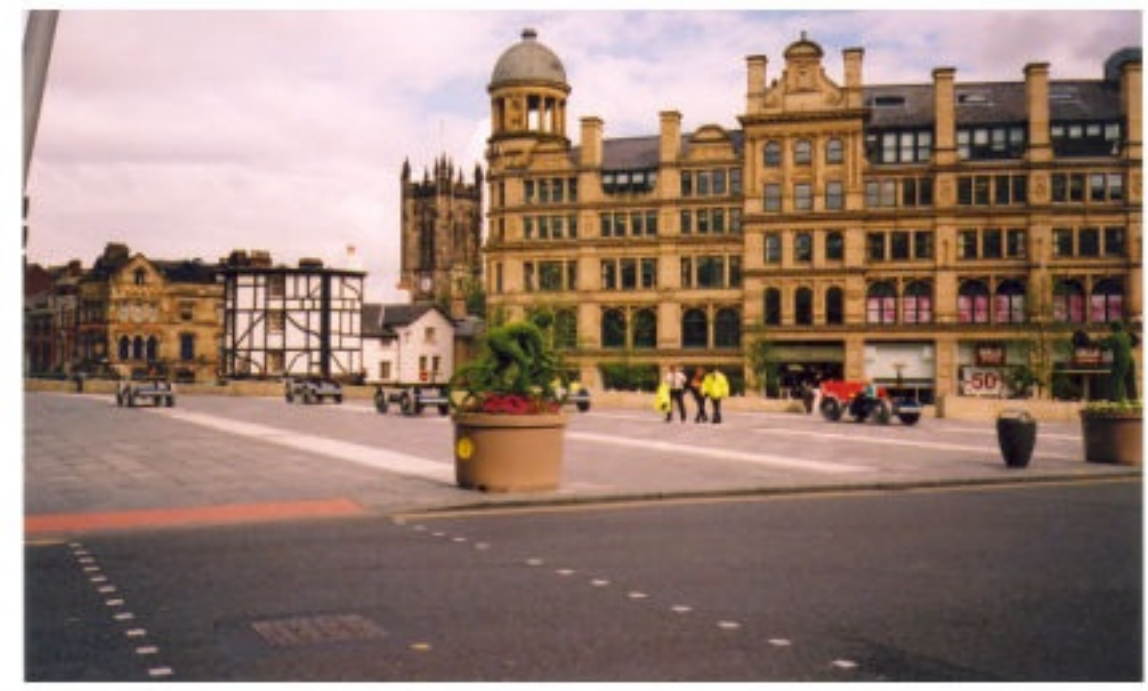

Image 1. The Millennium Quarter, Manchester

\section{Defining Gentrification}

"Gentrification refers to a process of class succession and displacement in areas broadly characterised by working-class and unskilled households first identified in the East End of London by Glass (1964)"(Atkinson 2000)

2.1 Gentrification can be broadly defined as the renewal of urban property by the middle and upper classes, especially in working class neighbourhoods. However, the physical and visual results of such a process are underpinned by more complex issues as

"underlying all these changes in the urban landscape are specific economic, social and political forces that are responsible for a major reshaping of advanced capitalist societies: there is a restructured industrial base, a shift to service employment and a consequent transformation of the working class and indeed the class structure in general [....]

Gentrification is a visible spatial component of this social transformation" (Smith and Williams 1986: 3).

2.2 One of the reasons gentrification is important is that it is a key theoretical and ideological battleground (Smith 1996). This battleground is occupied by two opposing sides; one concerned with culture, individual and consumer choice and the other with the importance of class, capital and shifts in social production (Smith 1996). These two antithetical views are compounded by Zukin in her 1995 work 'The Cultures of Cities'. How do the forces of gentrification affect the cultural and consumption options open to the individual? Indeed this is a question raised by Zukin who asks how can the city offer democratic culture when the city is being upgraded to appeal to the affluent? (Zukin 1995: 282). Hackworth, in agreement with this view, states that gentrification can also be defined as

"the production of urban space for progressively more affluent users " (Hackworth 2002: 815).

2.3 The displacement of one population and its culture by a more aspirant one has often been accompanied by a power struggle. In this sense gentrification can be viewed

"as a struggle of contending interests vying for control" (Betancur 2002: 780).

2.4 However, there is evidence to show that due to state intervention such struggles are now subsiding, therefore the views of the working classes are more easily contested and less protected (Hackworth and Smith 2001).

2.5 Hackworth and Smith (2001) argue that gentrification has experienced three waves with the most recent taking place between 1994 and 1999. Third wave post-recession gentrification is bigger and more powerful than in previous years, as corporate developers rework whole neighbourhoods, usually with state support. Gentrification traditionally focuses on the transformation of residential areas (see Butler and Robson 2001 and Atkinson 2000). However, more recently housing has been coalesced into the category of 'real estate', as Gibb and Hoesli argue

"real estate, encompassing housing, land and commercial property, is a key driver of the urban economy - in terms of economic development, the distribution of opportunities across 
2.6 Whilst rising property prices and a healthy housing market are fundamental to gentrification, it is evident that gentrifiers are no longer simply entrepreneurial individuals, looking to invest into what they consider to be an up and coming residential area. Gentrifiers are now large property development corporations, who often have state support. Arguably this has a detrimental impact on some who consume, produce or sell culture, specifically smaller independent traders who cannot compete with or afford to pay rental to large corporations. In addition to this the state sees fit to intervene to create gentrified areas as redevelopment is a way of generating tax revenues (Hackworth, $J$ and Smith 2001). Whilst the involvement of corporate developers and the state usually result in little opposition or struggle from existing communities there are exceptions to this (see for example Smith $1996^{[1]}$ ).

\section{The Political Economy of Gentrification}

3.1 What do Local Governments in the UK stand to gain from creating gentrified areas? In short they stand to gain revenues from residents and businesses in the region (Hackworth 2002, Hackworth and Smith 2001). In this way smaller cities such as Manchester can establish themselves as Headquarters cities (Taylor et al 1996) ${ }^{[2]}$. It is unsurprising that local economic developments are increasingly 'business- led' in urban areas. This involves the building of partnerships between local and national government and the private sector. Peck and Tickell argue that these partnerships are quite selective and unbalanced (1995: 55). In other words these partnerships are careful to include to certain groups and exclude to others, in fact,

"ironically, given their democratic origins and their effective exclusion of women, the unemployed, black people, community groups and other marginalized interests, a defining feature of these new 'partnerships' is their claim to 'speak for the city', and sometimes also for local people" (Peck and Tickell (1995: 56).

This means that local democracy becomes overtaken by private development interests.

3.2 In the case of Manchester there are a number of significantly powerful private partners who have emerged. They are known collectively as the Manchester Mafia as a result of the amount of power they have in the city ${ }^{[3]}$ (Peck and Tickell 1995). The emphasis is on promoting the growth of the city for those involved in setting the local economic development agenda. This has only been possible in Manchester, due to the City Council's willingness to work with a small and powerful elite group of businessmen. In short the involvement of private businesses in public/private business partnerships in Manchester has resulted in a 'privatisation' of urban politics, as power is apportioned between the 'Manchester Mafia' and the City Council. This 'privatisation' is of course a cause for concern as

"local business leaders are more likely to get involved with opportunistic 'shaking' than purposeful 'moving"' (Peck and Tickell 1995: 75).

Ultimately these people are businessmen with their own agendas and interests, which will probably become the interests of the city and its citizens as a whole.

3.3 The new logo for Manchester 'Making it Happen' (1990) in contrast to 'Defending Jobs Improving Services (1985) reflected political shifts within the city (Williams 2000: 489). The idea was to enhance Manchester's 'liveability' based around three assumptions: that Manchester was evolving along a postindustrial trajectory, that it must compete in a global market and therefore create its own unique brand image and finally class based divisions in the city must be overcome and a local 'team effort' made to ensure success (Williams 2000: 489). Part of this approach was the centralisation of culture and leisure industries as tools for improving economic growth and quality of life in the region. The Central Manchester Development Corporation (CMDC) came into existence, its aim being to promote economic diversity by attracting investment from the private sector into the city. 


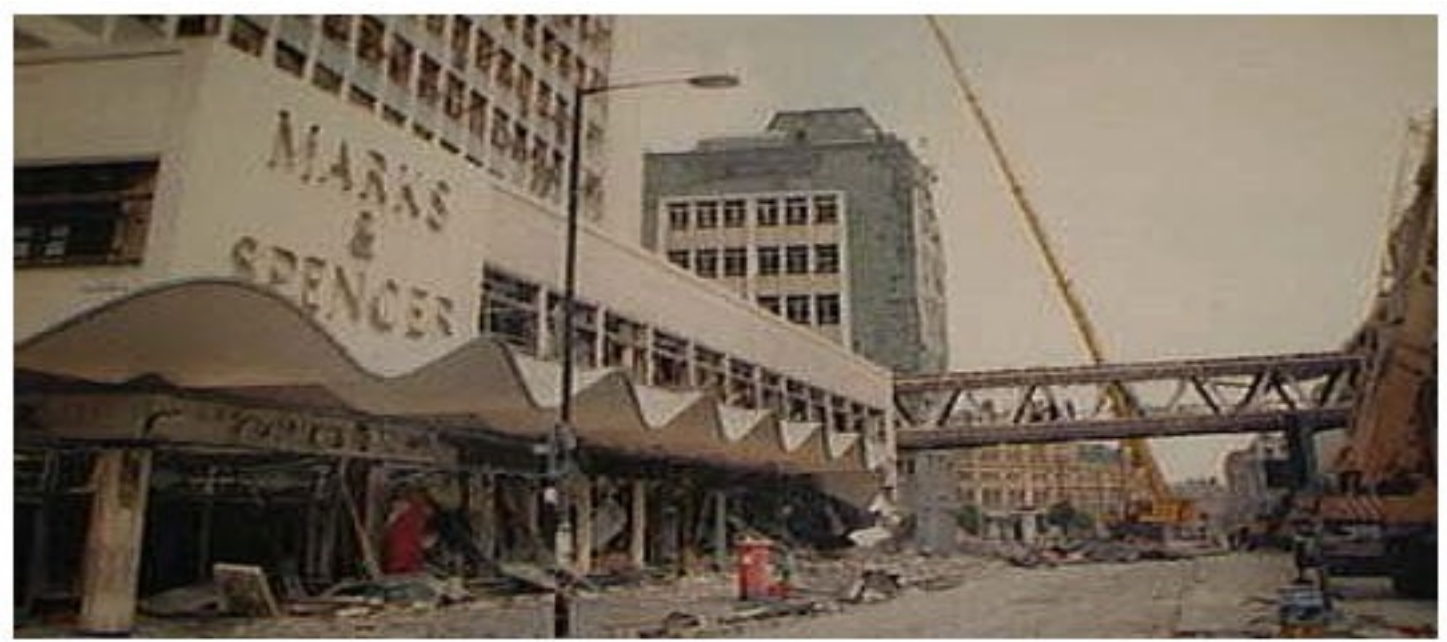

Image 2. Devastation of the city by the 1996 bomb (the Corn Exchange building is visible just behind the crane)

3.4 In 1996 central Manchester suffered immense physical, social and economic damage due to the IRA bombing. This resulted in the loss of around 49,000 square metres of prime retail space. An International Urban Design competition was launched to facilitate a planning response along with the establishment of a Task Force - Manchester Millennium Limited (MML, which disbanded in 2000) to co-ordinate the entire rebuilding process (Williams 2000: 492). The design competition facilitated the introduction of a publicprivate partnership (MML) to the city (Holden 2002). The brief for rebuilding the area included

\begin{abstract}
"the restoration and enhancement of the retail core and adding new cultural, entertainment and leisure destinations; ensuring accessibility, safety and security whilst creating an inviting pedestrian environment; building on historical strengths whilst delivering new urban development quality and a greener environment; and facilitating increasing residential population" (Williams 2000: 493).
\end{abstract}

3.5 EDAW construction won the competition due to their design making visual linkages in the city whilst maintaining key existing landmarks, linking streets and squares to ensure a pedestrian route and proposing an integrated transport system. More importantly they showed the most potential for enhancing the quality and potential for investment into the area, rather than merely redistributing previously existing activity (Williams 2000: 494-495). It is crucial to note that given much of this investment would be private it would make sense to such investors to appeal to those who would bring them the biggest financial gain i.e. the affluent. Whilst the city council were initially concerned about funding for the rebuilding process, their chief concern was to ensure that Manchester took advantage of the entrepreneurial opportunity it had been given (Holden 2002). The funding infrastructure consisted of an injection of public funds (£83 Million ${ }^{[4]}$ ) which attracted $£ 380$ million of private sector investment. The contribution from the public sector reduced the risk for private investors who viewed the area as a relatively safe bet, given that the Government were investing so confidently in it (Hackworth and Smith 2001). The public funding was earmarked for five specific elements: public realm improvements, transport infrastructure, the Urbis centre (a project to mark the millennium and chart the development and experience of the city), meeting new developments affected by deficit funding and management and promotion of the master plan programme (Williams 2000: 496). The key issue here is what impact would such a large private investment have on those able to consume, produce or sell culture in this newly regenerated area of the city?

\title{
The Gentrification of Consumption?
}

4.1 Early literature on gentrification focused on the middle class and its significant role in the transformation of the inner city. Part of this transformation involved issues such as in-movers, individual choice and of course consumer preferences (Betancur 2002). Later literature focuses more specifically on the causes rather than the effects of gentrification. It has been argued by Smith (1996) that capital, state policy, class, urban restructuring, investment and disinvestment are amongst the causes (Betancur 2002). In a political environment of privatisation it is predictable that both early and to a certain extent later literature is relevant with reference to Manchester's story.

4.2 In terms of consumption one of the ways in which gentrification physically manifests itself is via the appearance of exclusive designer boutiques and stores selling expensive goods. The inclusion of such retail outlets on the cityscape immediately excludes a large portion of the urban population, as those with limited income cannot afford to shop there. In this way the working classes are designed out of such areas which often don't appeal to them anyway ${ }^{[5]}$. The most extreme example of the gentrification of consumption 
in Manchester was the replacement of the Corn Exchange (which housed various market stalls selling everything from military memorabilia, to second hand records, comics and knives) with the Triangle (which sells nothing but luxury goods from champagne, to Calvin Klein underwear to nail manicures). The owners of the Corn Exchange building played a significant role here as

\begin{abstract}
"before the bomb, the owners of the Corn Exchange, the London-based Frogmore Investments Limited, had been the archetypal absentee landlord. With little interest in investing in either the stimulation of business activity or the Corn Exchange building itself, Frogmore's investment had become characterised by inertia and neglect [...] In December 1996 Frogmore terminated all the existing leases and announced its intention to refurbish the Corn Exchange in order to attract higher-quality retail units" (Holden 2002: 149).
\end{abstract}

4.3 This step towards gentrification had a severe negative impact on those allowed to trade in what was to become the Millennium Quarter. Inflated rents and Frogmore's desire to create a more upmarket image (which coincided with Manchester City Council's desire to be a more vibrant European city) priced certain consumers and traders of culture out of the area.

\title{
Winners and Losers
}

5.1 Betancur (2002) argues that gentrification is (unsurprisingly given that it is essentially about struggle and contest over urban space) a highly political process. In short the politics of gentrification is ultimately about the power of the existing community. This power refers not only to political prowess but also to economic capital. The intervention of the state is of paramount importance here, as ultimately the state will be more powerful than any existing population.

"The hidden hand is not so hidden in the process of gentrification [..] in fact it has a face - a set of forces manipulating factors such as class and race to determine a market outcome. In the end, it shows that community formations are as strong as their political and economic power. The most traumatic aspect of this analysis is perhaps the destruction of the elaborate and complex community fabric that is crucial for low-income, immigrant and minority communities - without any compensation" (Betancur 2002: 807).

5.2 In the case of Manchester one example of displacement caused by the bombing was that of the traders in the Corn Exchange. The diagram below (fig. 1) illustrates the displacement and dispersal of traders. The black arrows represent where the traders were repositioned. This visual representation indicates how their relocation led to their dislocation from each other, as they were scattered around the city centre in a fragmented way.

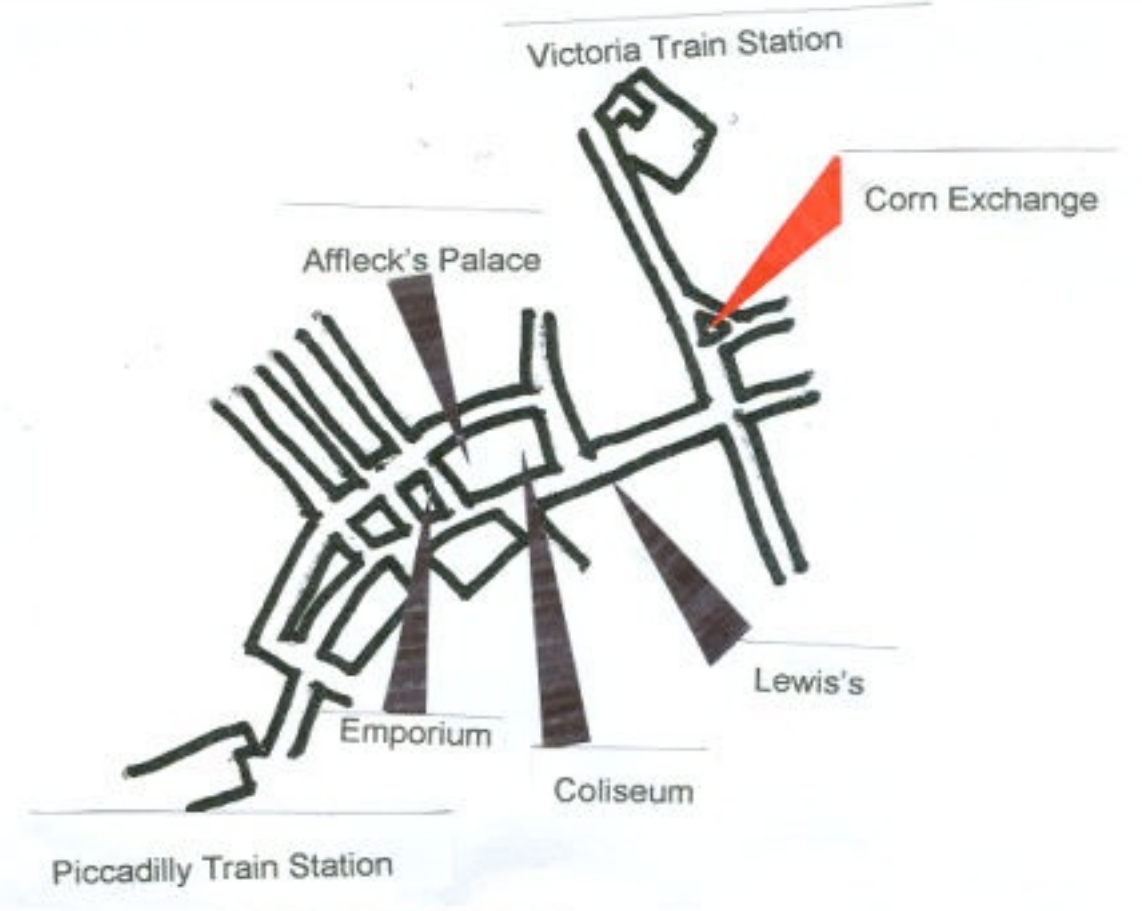

Figure 1. Displacement of Corn Exchange traders to various sites in Manchester post bomb

5.3 This displacement provided a short cut to gentrification and brought little conflict. There are three reasons for this 
1. the building was structurally unsafe and would be for a number of years, therefore the traders had to find new business premises

2. the then owners of the building (Frogmore) had recently taken over ownership of the building and were already running down the leases of established traders, with a view to attracting more affluent businesses

3. the traders were dispersed all over Manchester thus their daily contact was reduced and the pressure of trying to find new business premises left little time for campaigning.

5.4 Thus their political power was reduced due to the fragmentation of their community, as a result of the bomb and their already limited economic power was adversely affected. Indeed for many their only form of income came from the post bomb Lord Mayor's Fund (established by the City Council and consisting of donations from local businesses) as few were covered by insurance policies. This type of situation is not uncommon

"as gentrification continues and the working class is less able, as a whole, to afford rents in neighborhoods close to the central business district (CBD), prospects of an oppositional collective-consciousness are reduced" (Hackworth 2002: 824).

5.5 Clearly the Corn Exchange traders were 'priced out' of having businesses in the Millennium Quarter post-bomb. This has an impact on who can sell their wares or culture in this central urban space. The city council were more concerned with making

"the city centre into a cosmopolitan circuit of work and play intended to maximise its appeal to investors, so enhancing its image as the front stage for the region" (Mellor 2002: 230).

5.6 The independent traders from the Corn Exchange did not fit with such an image and thus were excluded from the newly regenerated Millennium Quarter. Whilst there was little visible conflict or protest on the part of the traders post-bomb, this does not mean it was not felt, as the following interviews highlight.

\section{Methodology}

6.1 In total seven traders affected by the bomb were interviewed. All interviews were semi-structured. This group was chosen for investigation as the aim was to articulate the experience of those who are usually absent from consultation and the political decision-making process. They proved to be quite a difficult group to locate as none of them occupy a centralised space in the city and the majority of them are no longer trading due to the economic damage they experienced. The traders were approached on an ad hoc basis. This involved going into the premises in which the respondents worked and informing them of my research. The majority of respondents were happy to oblige and gave an interview within one week of my approaching them. All interviewees gave their 'informed consent' (Silverman 2000) as they were all informed that the research was part of a PhD thesis being undertaken at Manchester Metropolitan University, which aimed to give a view on how use and perceptions of the Millennium Quarter have changed over time. All interviews were voluntary and anonymised (does your naming what type of trader they were compromise this or where there for example many stamp traders?). The interviews were tape recorded and transcribed. It is acknowledged that semi-structured interviews are open to criticism as they allow selective discussions to take place, thus making it easier for the researcher to produce biased data (Mann 1985). However, given that the aim of the research was to establish people's opinions and views qualitative methods were the most appropriate choice as

"qualitative research is concerned with individuals' own accounts of their attitudes, motivations and behaviour. It offers richly descriptive reports of individuals' perceptions, attitudes, beliefs, views and feelings, the meanings and interpretations given to events and things" (Hakim 1997: 26).

6.2 The research was carried out employing grounded theory approach (Glaser and Strauss 1995) which is defined as

"one that is inductively derived from the study of the phenomenon it represents. [.....] data collection, analysis, and theory stand in reciprocal relationship with each other. One does not begin with a theory, then prove it. Rather, one begins with an area of study and what is relevant to that area is allowed to emerge" (Strauss and Corbin 1990: 23).

6.3 The objective is not to prove a hypothesis, but instead to allow the theory to emerge from the data. Whilst there were key areas of investigation such as how urban space is used and by whom, who is included and excluded and what interviewees thought about the newly regenerated area, they were not tested but rather explored. 


\section{The Traders' Reality}

7.1 As previously stated the principal aim of this paper is to make public the opinions of the traders, who were excluded from the consultation process. More specifically it is hoped that the interview data will highlight the impact gentrification has had on the traders. Many traders spoke with fondness of the Corn Exchange, the different stalls there and the character of their owners. What is explored here is firstly, how the traders felt they were treated post-bomb in order to demonstrate how they felt they were excluded from the decision making process and the resultant changes and secondly, what they think of the 'improvements' made by the regeneration programme and the impact they believe the changes have had on the city centre and the lives of those who use it.

\section{The initial impact}

7.2 Opinions were fairly mixed on how the traders felt they were treated by the council. Everyone was in agreement that the Lord Mayor's Fund was a positive thing, though obtaining funds from it was not an easy process as those handling the funds were often fairly cynical about genuine cases.

"well everyone was obviously saying 'I need this I need that I need the other' but lot of them speaking to someone fairly high up in McVities and they gave a considerable chunk of money to that appeal and they were not happy with the way the money was handled, it was given as a gift and it was to be distributed as such. A lot of the people that actually went to the Lord Mayor's Fund they were given a loan rather than, although a lot of it was never asked to be returned, but there were people that were asking for silly thing and silly amounts of money I personally just asked for the amount for tables, desks and paint" (Stamp Dealer)

7.3 Arguably this quote also indicates that some traders may have been asking for a larger sum than they needed, but given that they had no access to their business premises for 8-10 weeks this is unsurprising what were they supposed to be selling given that most of their stock lay damaged in a building which was not structurally safe? The fact that traders had highly restricted access to their stock was another cause for concern

"I remember people it was getting on for months and then people had things nicked because there was workmen in there and you know there must have been a bit of grief really. A lot of the stock was obviously destroyed anyway because of you know the whole glass ceiling." (Skate and Workwear trader )

7.4 There doesn't appear to be a common process that all the traders went through in terms of getting back on their feet financially. Some received money from the Lord Mayor's Fund, others also received business start up loans and even those lucky enough to have insurance policies were fairly cynical about this process. One trader commented that there was a definite pecking order in terms of insurance claims, with Marks and Spencers at the top and smaller traders way down on the list of priorities. Whilst there is no hard evidence to substantiate such claims there was an incisive impression that the traders felt they were inconsequential to the rebuilding process. In terms of council support there is some disagreement amongst traders, with some saying that the Council were reasonably sympathetic up to three years after the bomb and others saying after 6 months they didn't want to know.

7.5 As already stated initially traders were dispersed all over Manchester but most of them relocated to the Northern Quarter, an area associated with small cultural or creative businesses and youth subcultures for the last ten to fifteen years - some went to the Emporium which opened on Oldham Street, others to Affleck's Palace and those from the Royal Exchange were housed on the third floor of Lewis's department store. Some attempt was made to offer a more unified space for the displaced traders when the Coliseum opened two months after the bombing. Not all the traders moved there straight away though, as some were already committed to leases on other premises. Sadly the Coliseum closed in June 2002 though three or four of the traders whose businesses have survived over the years now occupy a large unit in premises on Dale Street (Where is this? Is it evidence that they have been excluded from the centre. If you don't know Manchester the implications of what you are describing are not transparent).

7.6 Opinion on the way the then owners of the Corn Exchange (Frogmore) reacted to events was mixed. Some traders felt that the month's rent compensation offered was decent, though many knew that this was a small price to pay for the profits the Corn Exchange Building would bring in the future. For one trader there was no doubt that Frogmore saw the bombing as a definite window of opportunity

"Well basically we were all like low life slappers who were paying minimal rent you know, post card stalls and record shops and herbalists that were paying nothing rent, thirty quid, 
forty quid a week and of course they wanted rid of them and they wanted to get brand name companies in. It was so lucky for them, so lucky because like I said it did it all in one fell swoop and like I said they weren't renewing people's contracts anyway so they had that and obviously because people had length of contracts still to run they couldn't have got hold of them until they ran out so I mean it was just the luckiest thing" (House and Garage Record Imports trader).

7.7 How the traders were treated immediately after the bomb is relevant as it highlights the way in which their needs as small independent businesses were seen as insubstantial. Arguably this was because they did not 'fit' with enhancing Manchester's 'liveability' (Williams 2000) and certainly were certainly no match for selective and unbalanced public private partnerships (Peck and Tickell 1995) such as MML.

\section{The long term impact}

7.8 The former traders were asked what they thought of the area as a whole now and more specifically the Triangle (formerly the Corn Exchange). In terms of the Millennium Quarter as a whole, most traders thought that the area was more heavily used post regeneration, though there was still room for criticism.
"Just the sunny day pubs really it's nice to sit there it's a nice area it's a sun trap and it's nice to sit and watch the world go by there apart from that there's nothing there really. I would have thought that it could have been better used by maybe I don't know just some land where like when you go to a foreign country and you go to France and there's like an area where you've got people trying to sell you things but there's people performing and stuff I thought maybe a little bit more of that might have been going on". (hooded top trader)

7.9 Although the area is used by more people most traders agreed that the area has been designed with the affluent in mind and those in a higher income bracket are the main users of the area. Interestingly the Millennium Quarter has also attracted quite a large population of would be skateboarders, particularly on a Saturday afternoon (as most of them are teenagers). The attraction of a youth population is nothing new though as traders recalled that there were always loads of kids hanging about around the fountain during the years they occupied the Corn Exchange.

7.10 Everyone was in agreement that the Triangle was quite tastefully decorated both inside and out. However, one trader did use the term 'architecture without feeling' to describe the building. The design was not a problem on the whole but who was trading in there was. Some traders felt that the Triangle was 'Americanised' and full of chains and brands, thus the building no longer had the 'looser environment' of previous years. The issue of what the Triangle had to contribute to Manchester as a city was high on most traders list of priorities

"Well I think it's quite tastefully done but I think that's all I can say about it. I don't know whether it, because before it served a purpose didn't it? I think it served a purpose, it was a focal point for a lot of people admittedly in their own little group or circle but it was a focal point. ". (House and Garage Import records trader)

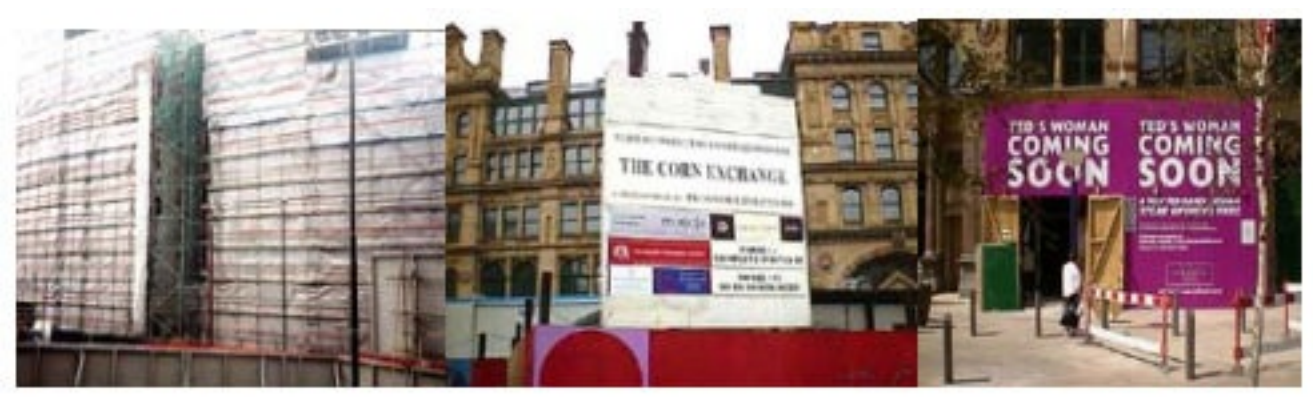

Images 3, 4 and 5. The Corn Exchange Building during the rebuilding process circa 1997- 2000

7.11 One trader expressed amusement that his war and military memorabilia unit was now selling ladies underwear, but on a more serious note there was also a sense that the Triangle had little sense of community, little to offer the visitor and little for the local to be proud of.

"I would have been more proud to visit because it had that feeling and it was more than anything Manchester people more or less, all the people weren't necessarily from Manchester but it very much had that community to it and like-minded appeal because we were all doing markets and you know more or less had the same kind of interests and it's more or less faceless now isn't it?" (Skate and Workwear Seller) 
7.12 Those occupying retail space in the Triangle were seen as dramatically different to the former traders.

"Well it's a different ball game altogether, it's upmarket, the other was like a market stalls on the inside and it's nothing like that now, all the big people there you know, big rents as well" (Second hand record dealer)

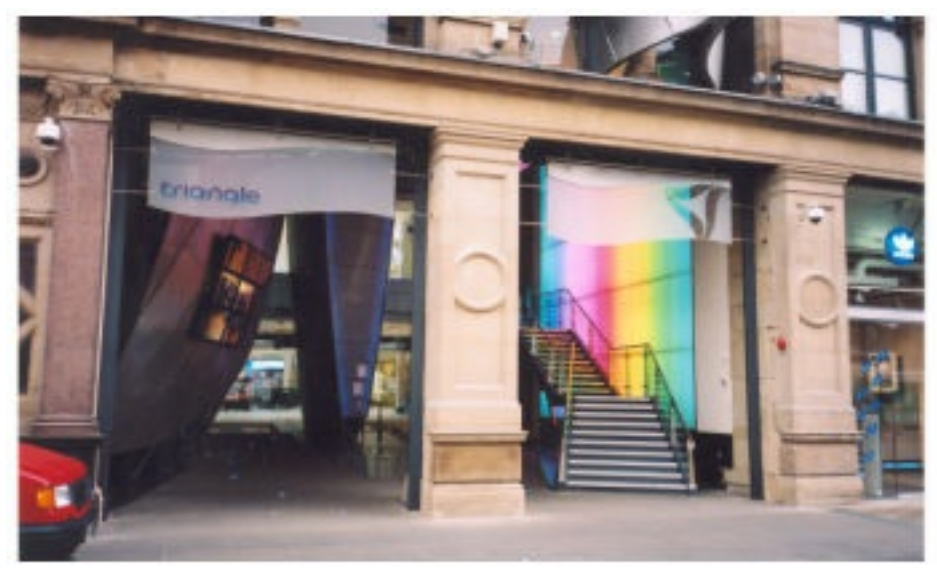

Image 6. The Triangle 2003

7.13 This difference was not only in terms of access to economic capital, though having experience of trying to set up a small business in a city was a key concern. Most traders agreed that starting a business in Manchester now was close to impossible.

"Not at all no. I mean in that way you won't get as many businesses like myself where you have an idea but you can't always get backing from a bank and you can like test it you can market research it by actually having a little stall and seeing if it works. Now you'll be committed to like leases you know 2 years whatever" (Hooded top trader)

7.14 Everyone was agreed that unless Manchester offers small businesses an area with less expensive rents, that small businesses could not get started and become bigger businesses and that this process does take 2 to 3 generations to occur. One trader had quite vivid yet distant memories of bygone Manchester when all stores were small and independent, before the Arndale displaced them just as the bomb led to the displacement of the Corn Exchange by the Triangle. He recalled that
"going way, way back before the Arndale was built when you had Market Street with every little side street with lots and lots of small businesses, everything you ever wanted you could find somewhere off Mark et Street and then they built the Arndale and all those little businesses just disappeared, it just reminded me of that. I mean when I was a kid my Dad used to bring me up Market Street and on a Saturday morning round there, there was anything and everything, you know anything you wants, Saddlers anything you wanted you could find somewhere off a side street, anything you wanted every conceivable business just all disappeared with the Arndale and it just gave the same impression" (Stamp seller)

7.15 The main concern for most traders though was what the bomb and what followed meant for the future of Manchester, not only in economic terms but in terms of the identity of the city and arguably in turn for those using the city as a base for the creation of identity via consumption. The following quote speaks for itself:

\begin{abstract}
"It gives the city an identity, I mean the Triangle could be any shopping centre in any city, anywhere and I mean yeah, it's done up nicely and you've got to thank them for that but it doesn't provide anything in way of substance to the city in any way shape or form". (House and Garage import record trader)
\end{abstract}

\title{
Conclusion
}

8.1 In the case of Manchester it is clear that the city has experienced the same shifts as many cities: from an industrial to post-industrial economy, with a decline in manufacturing and more importance placed on the role of the cultural economy (Harvey 1990, Wynne and O'Connor 1996). One feature of gentrification is that the affluent displace relatively poorer existing populations. In the case of the Corn Exchange/Triangle, it is clear that those who own retail premises in the Triangle have access to more capital than the previous market stall traders. The most important question though is how was this process of gentrification made possible? What were the economic, social and political conditions which allowed a relatively smooth 
transformation of the area? Hackworth and Smith's (2001) argument is relevant here as Manchester City Council intervened to ensure that the city was re-imaged to appeal to the affluent. However, this transition would not have been as easy had the owners of the Corn Exchange building not held such profit hungry corporate values. This supports Hackworth's (2002) argument that gentrification is strongly influenced by corporate developers. However, the example of Manchester does not fit easily in models which illustrate the experience of US cities. The circumstances which led to the Corn Exchange becoming the Triangle are much more complex. The bomb created an ideal opportunity and cut through a large amount of red tape, thus accelerating the transformation of the area. In other words the bomb acted as a catalyst for gentrification as it displaced traders, thus reducing any resistance and making the process less politicised. This leads to the crucial yet unanswerable question: how much of the gentrifying process was due to state intervention and corporate interests and how much was it largely circumstantial? This is something that will never be truly known, though the opinions of the traders show that many of them knew their future in the Corn Exchange was limited and somewhat uncertain even before the bomb. It should also be noted that the creation of the Triangle is not a straightforward example of gentrification - forces such as corporatisation and privatisation were at play in the rebuilding of this retail site. In this sense the Millennium Quarter is the exception that proves the rule, with reference to models of gentrification which traditionally focus on residential urban areas.

8.2 It is difficult to say whether the Millennium Quarter as a whole is currently more inclusive using the data presented here. However, it is clear that the Triangle is an exclusive rather than inclusive area. What is also evident is that the traders interviewed here were excluded due to their lack of cultural and economic power. For them the Triangle is not somewhere they can relate to, identify with or see themselves trading. Indeed, they were purposefully by-passed and omitted from any decisions about the future of the premises postbomb. It should be noted that this building is just one place in the Millennium Quarter which also has two new public spaces, which are more heavily populated by a large cross section of the general public. The story of these public spaces relies on another set of data and is of course another paper. The message of this paper though is that gentrification has an impact on who is allowed to produce, consume and sell culture in the city and ultimately this erodes the identity and individuality of urban spaces.

\section{Notes}

1 The protests which took place regarding Tompkins Square park in New York City, illustrate that gentrification usually results in conflict (Smith 1996).

2 Manchester's top ten companies include Airtours Leisure Travel, Great Universal Stores Home Shopping and Sharp Electronics (UK) all of whom have chosen to base their largest office spaces or headquarters in Manchester.

3 These include Bob Scott (Director of Manchester 2000 and Central Manchester Development Corporation, member of the Olympic Bid Committee and theatrical impresario), the Duke of Westminster (Chair of the North West Business Leadership Team, Manchester 2000 and landowner), Terry Thomas (Managing Director of the Co-operative Bank), Geoff Lord (Managing Director of Kellogg's and Director of Hulme City Challenge), David Plowright (Ex-Managing Director of Granada Television) and finally Sir Alan Cockshaw (Chair of AMEC construction).

${ }^{4}$ Economic Regional Development Fund $£ 20$ million, Department of Environment Transport and Regions $£ 43$ million and Millennium Commission $£ 20$ million

${ }^{5}$ The Millennium Quarter in Manchester is dominated by such exclusive retailers as Selfridges and a range of expensive boutiques in the Triangle (formerly the Corn Exchange). The exclusive retail image of the area has risen since Harvey Nichols opened its doors in 2003.

\section{References}

ATKINSON, R (2000) Measuring Gentrification and Displacement in Greater London in Urban Studies, Vol. 37, No. $1,149-165$

BETANCUR, J (2002) The Politics of Gentrification: The Case of West Town in Chicago, Urban affairs Review, July 2002, Vol. 37 , No. $6,780-814$

BUTLER, T and Robson, G (2001) Social Capital, Gentrification and Neighbourhood Change in London: A Comparison of Three South London Neighbourhoods in Urban Studies, Vol. 36, No. 12, 2145-2162 
CHATTERTON, P. and Hollands, R. (2003) Urban Nightscapes: Youth Cultures, Pleasure Spaces and Corporate Power, London: Routledge.

GLASER, B and Strauss, A (1995) The Discovery of Grounded theory: Strategies for Qualitative Research, New York: Aldine De Guyter

GIBB, K and Hoesli M (2003) Developments in Urban Housing and Property Markets in Urban Studies, Vol. 40, Nos. 5-6, 887-896

HACKWORTH, J (2002) Postrecession Gentrification in New York City, Urban Affairs Review, Vol. 37, No. 6, July 2002, 815-843

HACKWORTH, J and Smith, N (2001) The Changing State of Gentrification, Tijdschrift voor Economische en Sociale Geographie, Vol. 92, No. 4, 161-177

HAKIM, C (1997) Research Design: Strategies and Choices in the Design of Social Research London: Routledge

HAMNETT, and Randolph, B (1984) The Role of landlord Disinvestment in Housing Market Transformation: An Analysis of the Flat Break-up Market in Central London in Transactions of the Institute of British Geographers, Vol. 9, 259-279

HARVEY, D (1990) The Condition of Postmodernity, Blackwell: London

HOLDEN, A (2002) Bomb Sites: The Politics of Opportunity in Peck, J and Ward, K (Eds.) City of Revolution: Restructuring Manchester, Manchester, Manchester University Press

MANN, P, H (1985) Methods of Social Investigation, Oxford: Blackwell

LOW, S. (2000) On the Plaza: the politics of public space and culture, ( $1^{\text {st }}$ edition) Texas; University of Texas Press.

MELLOR, R (2002) Hypocritical City: Cycles of Urban Exclusion in Peck, J and Ward, K (Eds.) City of Revolution: Restructuring Manchester, Manchester, Manchester University Press

PECK, J and Tickell, A (1995) Business Goes Local: Dissecting the 'Business Agenda' in Manchester, International Journal of Urban and Regional Research, Vol. 19, No. 1, 57-78

ROBSON, G and Butler, T (2001) Coming to Terms with London: Middle-Class Communities in a Global City in International Journal of Urban and Regional Research, Vol. 25, No. 1, 70-86

ROSENBURG, L and Watkins, C (1999) Longitudinal Monitoring of Housing Renewal in the Urban Core: Reflections on the Experience of Glasgow's Merchant City in Urban Studies, Vol. 36, No. 11, 1973-1996.

SILVERMAN, D (2000) Doing Qualitative Research: A Practical Handbook, London: Sage

SMITH, N (1996) The New Urban Frontier: Gentrification and the Revanchist City, Routledge. London

SMITH, N and Williams, P (Eds.) (1996) Gentrification of the City, Allan and Unwin, USA

STRAUSS, A and Corbin, J (1990) Basics of Qualitative Research: Grounded Theory Procedures and Techniques London: Sage

TAYLOR et al (1996) A Tale of Two Cities: Global Change, Local Feeling and Everyday Life in the North of England - A Study in Manchester and Sheffield, Routledge, London

WILLIAMS, G (2000) Rebuilding the Entrepreneurial City: The Master Planning Response to the Bombing of Manchester City Centre, Environment and Planning: Planning and Design, Vol. 27, 485-505

WYNNE, D and O'Connor, J (Eds.) (1996) From the Margins to the Centre, Aldershot, Arena

ZUKIN, S (1995) The Cultures of Cities, Blackwell, London 